\title{
Implementasi Asisten Virtual Dalam Komunikasi Pelayanan Pelanggan (Studi Kasus Pada Layanan Pelanggan Telkomsel)
}

\author{
Rangga Putera Perdana, Irwansyah \\ Universitas Indonesia \\ J1. Salemba Raya No. 4, Jakarta Pusat \\ halorangga@gmail.com,dr.irwansyah.ma@gmail.com
}

Masuk tanggal: 08-09-2019, revisi tanggal: 15-11-2019, diterima untuk diterbitkan tanggal: 26-11-2019

\begin{abstract}
The virtual assistant is basically a series of programming languages based on NLP (Natural Language Program) that allow users to talk and get responses in the form of replies from applications in the same way as what happens to other individuals. The purpose of this research is to know the form of implementation of virtual assistants in the field of customer service in Telkomsel. The method used in this research is descriptive qualitative by collecting data through interviews and literature studies. The results of this study explain the implementation of chatbot and AI technology in the Telkomsel virtual assistant. Even so, aspects of human resources still play a role in training AI to understand what is written by customers. The Telkomsel virtual assistant uses the Facebook Messenger, Line and Telegram social networks, and has been implemented on the Telkomsel website and the myTelkomsel application. The form of development that will be carried out is to add WhatsApp, make improvements to AI, migrate technology from version one to version three and collaborate with Google Assistant.
\end{abstract}

Keywords: Virtual Assistant, Chatbot, Customer Services

\begin{abstract}
Abstrak
Asisten virtual pada dasarnya merupakan serangkaian bahasa pemograman dengan basis NLP (Natural Language Program) yang memungkinkan pengguna untuk berbicara dan mendapatkan respon berupa balasan dari aplikasi dengan cara yang sama halnya dengan apa yang terjadi pada individu-individu lainnya. Tujuan dari penelitian ini adalah mengetahui bentuk implementasi asisten virtual dalam bidang pelayanan pelanggan di Telkomsel. Metode yang digunakan dalam penelitian ini adalah kualitatif deskriptif dengan pengumpulan data melalui wawancara dan studi literatur. Hasil penelitian ini menjelaskan tentang implementasi teknologi chatbot dan AI pada asisten virtual Telkomsel. Walaupun begitu, aspek sumber daya manusia masih berperan dalam melatih AI untuk memahami apa yang dituliskan oleh pelanggan. Asisten virtual Telkomsel menggunakan jejaring sosial Facebook Messenger, Line dan Telegram, serta sudah terimplementasi pada situs web Telkomsel dan aplikasi myTelkomsel. Bentuk pengembangan yang akan dilakukan yaitu menambah WhatsApp, melakukan peningkatan pada AI, migrasi teknologi dari versi satu ke versi tiga dan melakukan kolaborasi dengan Google Assistant.
\end{abstract}

Kata Kunci: Asisten Virtual, Chatbot, Pelayanan Pelanggan 


\section{Pendahuluan}

Komunikasi merupakan salah satu ranah dalam ilmu sosial yang memiliki banyak implementasi didalam kehidupan bermasyarakat. Selain sebagai kebutuhan seorang individu untuk bisa tetap hidup, komunikasi juga menjadi salah satu dasar dari perkembangan teknologi yang semakin marak dilakukan pada hari ini. Perkembangan teknologi dalam ranah komunikasi sejatinya dilakukan untuk semakin mempermudah individu-individu dalam masyarakat untuk berinteraksi satu sama lain. Munculnya teknologi fisikseperti telepon genggam dan komputer-serta teknologi perangkat lunakseperti sistem operasi dan situs-menjadi sedikit dari banyaknya contoh teknologi untuk mempermudah proses komunikasi antar individu. Bentuk komunikasi yang sebelumnya biasa dilakukan secara langsung — tatap mukakini banyak berubah ke bentuk komunikasi tidak langsung (Kamil, 2016).

Teknologi membuat nyaman individu dalam berkomunikasi, karena ia meminimalisir kehadiran serta jarak diantara pelaku komunikasi. Salah satu bentuk interaksi yang tercipta dari hadirnya kolaborasi antara teknologi dan komunikasi ini ialah interaksi maya, dimana individu tidak perlu hadir di satu tempat dan waktu yang sama hanya untuk melakukan interaksi. Hadirnya beberapa platform seperti media sosial hingga layanan penyedia musik maya mampu melakukan hal tersebut (Netti, 2018)

Aspek lain yang turut merubah cara individu dalam berinteraksi maupun berkomunikasi juga terjadi pada sisi pelayanan pelanggan. Banyak industri produk maupun jasa yang terus melakukan inovasi dalam hal pelayanan pelanggan. Pelanggan merupakan pemangku kepentingan yang harus diperhatikan secara khusus bagi pelaku bisnis - terutama mereka yang sudah loyal kepada produk atau jasa hingga bertahun-tahun. Mempertahankan kepuasan dan kenyamanan pelanggan dalam menggunakan produk dan jasa menjadi salah satu tantangan perusahaan yang harus dihadapi. Pelayanan pelanggan atau customer service diatikan sebagai suatu bagian dari perusahaan yang memiliki fungsi sebagai sumber informasi sekaligus perantara bagi pelanggan yang ingin mendapatkan jasa pelayanan maupun produk (Kotler \& Armstrong, 2012). Bagian pelayanan pelanggan inilah yang kemudian menjadi ujung tombak dari perusahaan dalam berinteraksi dengan pelanggan. Serupa dengan komunikasi, pelayanan pelanggan memiliki fungsi yang sama, yaitu memberikan informasi, mengedukasi, menghibur serta memberikan pengaruh kepada pelanggan untuk meningkatkan pembelian atau mempertahankan loyalitasnya. Tidak mengherankan jika fungsi pelayanan pelanggan sama dengan fungsi komunikasi, karena memang pada dasarnya pelayanan pelanggan dibangun dari komunikasi yang baik dengan pelanggan.

Bentuk interaksi pelayanan pelanggan ini-pun terbagi menjadi tiga yaitu, pelayanan dengan lisan-contohnya ialah kehadiran call center, pelayanan dengan tulisan-contohnya ialah sarana email keluhan pelanggan, dan pelayanan dengan perbuatan - contohnya ialah penempatan customer service representative pada kantor-kantor cabang (Munir, 2006). Persamaan dari ketiganya yaitu terdapat teknologi yang menjadi perantara antara pelanggan 
dengan bagian pelayanan pelanggan. Teknologi yang dimaksud disini adalah medium analog maupun digital yang berfungsi sebagai gatekeeper informasi dari pelanggan ke bagian pelayanan pelanggan. Contohnya adalah, jika bentuk pelayanan yang digunakan itu berbasis lisan-call center - maka teknologi yang digunakan ialah telepon atau telepon genggam. Lalu, jika bentuk pelayanan lain yang digunakan ialah tulisan, maka teknologi yang digunakan ialah teknologi berbasis digital seperti surat elektronik maupun situs. Bahkan tidak jarang jika bentuk pelayanan yang digunakan itu adalah secara perbuatan, pelanggan seolah-olah "dipaksa" untuk hadir secara fisik ke kantor cabang terdekat hanya untuk menyampaikan keluhannya. Ketiga bentuk pelayanan pelanggan tersebut kemudian lebih dikenal dengan istilah bentuk konvensional-dimana pelanggan masih memerlukan usaha lebih untuk menyampaikan atau mendapatkan informasi yang ia butuhkan.

Namun, seiring dengan perkembangan teknologi dan komunikasi, banyak perusahaan yang mulai meninggalkan kreasi bentuk pelayanan pelanggan yang konvensional. Hal ini didasarkan pada perubahan pola dan perilaku individu dalam berinteraksi, khususnya dalam bidang pelayanan. Seperti yang sudah dijelaskan sebelumnya, pelanggan sebagai individu dalam masyarakat juga sudah terpapar perkembangan teknologi komunikasi yang membuat cara pendekatan ke mereka turut berubah. Pelanggan yang nyaman menggunakan telepon genggam ataupun sarana Internet pasti akan berpikiran dua kali untuk berpergian ke kantor cabang terdekat hanya untuk difasilitasi oleh bagian pelayanan pelanggan. Untuk itulah, banyak dari perusahaan yang memusatkan bisnisnya dari pelanggan berlomba-lomba mencari alternatif baru dalam hal pengembangan layanan pelanggan.

Munculnya asisten virtual-virtual assistant - pada kanal media baru dewasa ini menjadi penanda dimulainya era baru dalam industri pelayanan pelanggan. Teknologi bernama asisten virtual ini hadir sebagai jawaban dari bentuk transformasi pelayanan pelanggan dari konvensional ke digital. Hal lain yang menjadikan asisten virtual ini unik ialah kehadirannya yang dimaksudkan untuk pembentukan interaksi dengan pengguna manusia secara alami, baik itu secara kognitif, linguistik maupun kolaboratif (Bernard \& Arnold, 2019). Asisten virtual hadir dalam berbagai bentuk antarmuka, seperti audio, teks, gambar, UI, kontrol maupun konten web (Beaver \& Freeman, 2017). Fleksibelitas asisten virtual dalam mengakomodir segala bentuk media menjadi salah satu kelebihan yang ditawarkan dari teknologi ini. Ia dapat berbentuk suara, teks, gambar maupun gabungan ketiganya. Selain itu, teknologi asisten virtual ini juga mengedepankan kapabilitas individu sebagai pelanggan untuk lebih banyak memegang kontrol dari informasi yang ingin mereka ketahui. Di sisi lain, perusahaan bisa menggunakan data yang mereka miliki untuk diolah sedemikian rupa sehingga informasi yang diinginkan oleh pelanggan melalui asisten virtual dapat terpenuhi.

Asisten virtual pada dasarnya merupakan serangkaian bahasa pemograman dengan basis NLP (Natural Language Program) yang memungkinkan pengguna untuk berbicara dan mendapatkan respon berupa balasan dari aplikasi dengan cara yang sama halnya dengan apa yang terjadi pada 
individu-individu lainnya (Guzman, 2019). NLP juga merupakan salah satu fokus dalam pengembangan kecerdasan buatan dari sisi linguistik komputasi. Data mining, pengenalan suara otomatis, tranformasi teks ke ucapan sampai halnya pada sintesis pidato merupakan sedikit contoh dari banyaknya bentuk teknologi yang diintegrasikan pada asisten virtual (Lasek, n.d.). Sistem komputerisasi yang menjalankan program asisten virtual ini kemudian melakukan serangkaian tugas dengan menggunakan pengetahuan linguistik dan keterampilan berbicara ala manusia, sehingga meningkatkan komunikasi manusia dan mesin dengan cara memproses secara otomatis teks dan/atau ucapan yang dikehendaki.

Chatbot, merupakan program komputer yang mensimulasikan percakapan manusia melalui kecerdasan buatan. Ia memungkinkan mesin untuk berinteraksi dengan manusia pada domain tertutup melalui teks tertulis atau interaksi suara, dengan atau tanpa bantuan manusia lainnya (Simon, 2019). Chatbot inilah kemudian yang menjadi turunan dari asisten virtual dimana antarmuka pengguna dari percakapan ini mengikuti grafis antarmuka pengguna yang akrab bagi kebanyakan orang. Tidak heran jika kemudian chatbot banyak diimplementasikan perusahaan pada media sosial berbasis percakapan - seperti LINE, Telegram, Facebook Messenger dll—untuk bisa berkomunikasi langsung dengan pelanggan. Melalui sarana chatbot pada media sosial berbasis percakapan ini, perusahaan dapat dengan leluasa melakukan kustomisasi jenis pelayanan yang ingin diberikan kepada pelanggan. Dari sisi pelanggan pun juga dimudahkan dengan beragam pilihan layanan yang dituju tanpa harus repotrepot melakukan usaha lebih. Jenis layanan yang dapat dilakukan oleh asisten virtual dalam sarana chatbot ini diantaranya adalah, pengecekan status, pelaporan keluhan atau saran, medium informasi ataupun promosi dan sarana penjualan produk terkait.

Telkomsel, sebagai salah satu pemain besar dalam industri telekomunikasi selular tentu memusatkan perhatiannya pada keberlangsungan kualitas dan daya beli penggunanya. Untuk itulah salah satu hal yang menjadi fokus dalam pengembangan bisnis di masa depan adalah bagaimana perusahaan dapat lebih memberdayakan aspek pelayanan pelanggan. Telkomsel sendiri tercatat memiliki berbagai bentuk layanan pelanggan yang dapat dimanfaatkan oleh penggunanya. Mulai dari keberadaan offline customer touch point berupa Grapari, layanan pelanggan melalui telepon yaitu Caroline-Call Centre On Line, hingga bantuan rekan-rekan media sosial Telkomsel melalui platform email, Facebook hingga Twitter, siap sedia membantu pelanggan yang mengalami kendala perihal layanan Telkomsel yang mereka rasakan. Keragaman bentuk pelayanan pelanggan inilah yang lantas membuat Telkomsel mendapatkan beberapa penghargaan di bidang pelayanan pelanggan atas dedikasi serta inovasi yang dilakukan. Penghargaan bergengsi seperti WOW Service Excellence Award 2016 serta Frost \& Sullivan Best Practices tahun 2014 dan 2018 pun tidak luput untuk dibawa pulang.

Dalam ranah penelitian akademis, topik mengenai asisten virtual dengan fokus utama di sisi pelayanan pelanggan terhitung masih sangat minim. Mayoritas penelitian yang terpublikasi secara ilmiah dari topik ini lebih 
menitikberatkan pada aspek teknikal atau teknologi yang diusung asisten virtual. Walaupun tidak memberikan fokus pada aspek pelayanan pelanggan pada bidang jasa telekomunikasi, tetap ada beberapa penelitian yang beririsan dengan topik dalam penelitian ini, dua diantaranya berfokus pada bidang perhotelan dan barang-barang mewah. Hasil penelitian tentang asisten virtual yang diimplementasikan pada kinerja hotel menunjukkan bahwa personalisasi yang dilakukan pada asisten virtual dapat mengumpulkan lebih banyak pemesanan langsung, dibandingkan jika harus melalui pihak ketiga. Hasil lain menunjukkan bahwa desain sistem secara kualitatif mengubah proses interaksi atau hubungan serta dapat menginduksi emosi dan meningkatkan perasaan afektif terhadap penyedia layanan. Hingga pada akhirnya, tercipta peningkatan hubungan antara hotel dan pelanggan yang kemudian menciptakan preferensi pelanggan yang menguntungkan bagi pihak hotel (Piccoli, Lui, \& Grün, 2017).

Pada penelitian berikutnya, ditemukan bahwa asisten virtual juga memiliki kontribusi positif dalam aspek kepuasan pelanggan yang biasa mengonsumsi produk-produk dengan merek premium. Pelanggan merek premium tersebut nyatanya membutuhkan persepsi komunikasi yang berkualitas pada produk yang mereka beli atau gunakan. Asisten virtual juga menunjukkan bahwa kanal digital dapat membantu perusahaan dalam membangun hubungan pelanggan yang positif-walaupun agen layanan digital ini tidak sepenuhnya berkomunikasi dengan pelangan (Chung, Ko, Joung, \& Kim, 2018). Merujuk pada paparan konsep, objek penelitian, serta hasil penelitian terdahulu, penulis tertarik untuk mendalami topik tentang asisten virtual ini dengan pertanyaan penelitian, bagaimana implementasi asisten virtual pada komunikasi pelayanan pelanggan Telkomsel. Adapun tujuan dari penelitian ini ialah untuk memberikan gambaran secara deskriptif tentang bentuk implementasi yang dilakukan Telkomsel dalam menggunakan teknologi asisten virtual pada bidang komunikasi pelayanan pelanggannya.

\section{Metode Penelitian}

Pendekatan yang digunakan dalam penelitian ini adalah pendekatan kualitatif dengan fokus penjabaran secara deskriptif. Studi deskriptif kualitatif merupakan suatu penelitian yang mendeksripsikan atau menggambarkan sebuah fenomena secara sistematis sesuai apa adanya untuk menemukan informasi mengenai keadaan saat ini dan berusaha untuk memaparkan keadaan yang sesungguhnya sesuai rumusan masalah yang diajukan (Dantes, 2012). Melalui pendekatan ini, peneliti bisa dengan mudah menggambarkan secara detil terkait tentang implementasi asisten virtual pada pelayanan pelanggan Telkomsel. Selanjutnya, metode yang digunakan dalam penelitian ini adalah studi kasus. Studi kasus merupakan sebuah metode untuk menggali kasus tertentu dalam suatu waktu dan kegiatan, serta mengumpulkan informasi secara terinci dan mendalam dengan menggunakan berbagai prosedur pengumpulan data selama periode tertentu (Cresswell, 2015). Penelitian ini menggunakan metode studi kasus karena bertujuan untuk memaparkan kasus, tidak mencari atau menjelaskan hubungan, serta tidak menguji hipotesis ataupun membuat prediksi. 
Kehadiran teknologi asisten virtual menjadi contoh kasus yang menarik dalam bidang komunikasi pelayanan pelanggan, karena menawarkan suatu pengalaman yang berbeda dari bentuk-bentuk sebelumnya. Oleh karena itu, penelitian ini akan berfokus pada teknologi asisten virtual yang digunakan dalam bidang pelayanan pelanggan terutama di industri jasa telekomunikasi.

Metode pengumpulan data diartikan sebagai serangkaian cara yang digunakan peneliti untuk mengumpulkan data. Teknik pengumpulan data dalam penelitian komunikasi yaitu kuisioner (angket), interview (wawancara), observasi (pengamatan), dokumentasi dan catatan pengalaman lapangan (Pujileksono, 2015). Fokus pengumpulan data dalam penelitian ini yaitu berupa wawancara dan pengumpulan dokumen literatur/kajian literatur-baik itu online maupun offline - yang berkaitan dengan topik penelitian. Jenis wawancara yang digunakan adalah wawancara yang terstruktur, sehingga informasi yang diterima dapat digambarkan secara jelas.

Objek pada penelitian ini ialah asisten virtual yang dikembangkan oleh Telkomsel dalam melayani pelanggannya. Pemilihan objek dilandasi oleh beberapa pertimbangan, diantaranya ialah keseriusan Telkomsel dalam memberikan pelayanan nomor satu kepada para pelanggannya, sehingga mereka selalu terbuka dalam menghadapi perkembangan pasar dan teknologi komunikasi terbaru. Ini ditandai dengan pencapaian Telkomsel dalam meluncurkan asisten virtual miliknya yang menjadi pionir diantara pemain industri telekomunikasi. Hal lainnya ialah kapabilitas Telkomsel dalam mengembangkan asisten virtualnya — yang mulanya hanya di satu platform saja, namun kini sudah merambah ke berbagai media digital.

Adapun subjek penelitian kali ini yaitu salah seorang dari tim pengembangan dan operasional asisten virtual Telkomsel, yaitu Wandi Yanuar Fernando. Subjek penelitian yang dipilih merupakan karyawan organik yang sudah melakukan pengembangan asisten virtual Telkomsel selama tiga tahun, sehingga diharapkan dapat memberikan gambaran yang jelas perihal asisten virtual milik Telkomsel. Pemilihan subjek penelitian didasari pada tujuan penelitian, serta mempermudah peneliti dalam menyajikan informasi mengenai teknologi dan bentuk implementasi dari asisten virtual yang digunakan dalam bidang pelayanan pelanggan Telkomsel. Lokasi penelitian berada di Jakarta, mengacu pada posisi informan yang bekerja di kantor pusat Telkomsel di Jakarta. Selain menempatkan hasil wawancara sebagai data primer, penulis juga menggunakan dokumen literatur sebagai acuan data sekunder dan melengkapi data utama.

Lalu, teknik analisis data yang digunakan dalam penelitian ini mengacu pada model Miles dan Huberman, yaitu dengan melakukan reduksi data, penyajian data dan penarikan kesimpulan serta verifikasi (Pujileksono, 2015). Teknik analisis data model ini dapat memudahkan peneliti dalam melakukan kajian analisis mendalam dari hasil wawancara serta dokumen literatur yang sebelumnya sudah dikumpulkan. Reduksi data dilakukan untuk memfilter informasi-informasi yang berkenaan dengan topik penelitian ataupun tidak. 
Rangga Putera Perdana, Irwansyah: Implementasi Asisten Virtual Dalam Komunikasi Pelayanan Pelanggan (Studi Kasus Pada Layanan Pelanggan Telkomsel)

\section{Hasil Penemuan dan Diskusi}

PT. Telekomunikasi Selular merupakan sebuah perusahaan yang bergerak di bidang jasa telekomunikasi dan dibentuk pada tanggal 26 Mei 1995. Perusahaan yang terkenal dengan merek dagang Telkomsel ini memiliki varian produk yang dapat dipilih dan digunakan oleh penggunanya. Varian produk tersebut terdiri dari voice, SMS dan data. Untuk produk suara dan SMS, Telkomsel memiliki beberapa merek untuk menyasar beberapa segmentasi seperti kartuHalo untuk kelas menengah ke atas, simPATI untuk kelas menengah, kartuAS untuk kelas menengah ke bawah dan LOOP yang diperuntukkan untuk segmentasi kalangan muda. Untuk produk data sendiri Telkomsel hanya memiliki satu merek yaitu Telkomsel Flash. Saat ini jumlah pengguna yang tercatat menggunakan layanan Telkomsel yaitu sebesar 167,8 juta orang. Tidak heran jika kemudian Telkomsel mencatatkan dirinya sebagai pemimpin pasar di bidang jasa telekomunikasi di Indonesia.

Satu persamaan yang melingkupi keseluruhan produk tersebut ialah muara bentuk pelayanan pelanggannya yang sama. Pelanggan dari berbagai merek dibawah Telkomsel akan mendapatkan bentuk pelayanan yang sama. Adapun bentuk pelayanan pelanggan yang dimiliki Telkomsel ini terbagi menjadi dua jenis, yaitu assisted dan self-service.

Jadi kalo lebih spesifiknya social media itu kan banyak sebenernya ada yang Assisted, ada yang self-service. Kalo yang Assisted itu yang ada agentnya, contohnya Twitter, kemudian Facebook Wall, email, itu Assisted. Sedangkan selfservice ini kan yang memang tidak ada sumber daya manusia disitu. (Wandi Yanuar Fernando, 22 Mei 2019)

Seperti yang sudah dijelaskan oleh Wandi, bentuk pelayanan pelanggan yang assisted memiliki ciri khas pada aspek "pelayanan yang dilakukan oleh agen/orang", contohnya adalah pelayanan pelanggan di media sosial Telkomsel-eCare, agen call center-Caroline (Call Center On-Line) dan agen yang berada di Grapari. Selanjutnya yang membedakan dengan bentuk pelayanan pelanggan self-service ini adalah ketiadaan agen/orang yang melayani pelanggan. Contoh dari bentuk pelayanan pelanggan ini ialah asisten virtual Telkomsel yang diberi nama Veronika. Pemisahan kedua bentuk pelayanan pelanggan tersebut dilakukan guna memberikan pilihan dan meningkatkan kualitas layanan (Chung et al., 2018)

\section{Implementasi Asisten Virtual di Pelayanan Pelanggan Telkomsel}

Pada tahun 2017 silam, Telkomsel mendahului para kompetitornya dengan mengeluarkan inovasi terbaru di bidang pelayanan pelanggan. Veronika, sebenarnya bukan nama baru yang dicetuskan oleh Telkomsel. Mulanya, Veronika diperkenalkan sebagai suara perempuan yang muncul untuk menyapa pelanggan Telkomsel ketika panggilan yang dilakukan oleh pengguna tersebut tidak dijawab oleh nomor tujuan (Atmoko, 2017). Uniknya, suara perempuan tersebut muncul dari sebuah mesin penjawab otomatis yang dirancang sedemikian rupa hingga kemudian suara yang dikeluarkan bisa terdengar sebagai suara perempuan. Suara perempuan inilah yang diberikan nama sebagai 
Veronika (Voice Response and Info Care). Beberapa tahun kemudian, tepatnya pada tanggal 24 Agustus 2018, Veronika kembali hadir menyapa pelangganpelanggan setia Telkomsel dengan membawa bentuk dan semangat baru. Veronika 2.0 ini bertransformasi menjadi asisten virtual yang diperuntukkan khusus pelanggan Telkomsel. Menurut Wandi, asisten virtual Telkomsel ini lahir setelah melalui proses yang cukup panjang, mulai dari melakukan benchmark hingga menganalisis tren layanan digital yang semakin meningkat.

Karna kita liat tren. Kan kalo pengguna, kalo kita sering liat di wearesocial itu kan tren pengguna social media itu meningkat. Pokoknya digital service tuh meningkat drastis, sementara legacy itu ya konstan dan cenderung menurun. Nah kemudian kita mulai, mungkin beberapa senior saya itu berpikir, gimana kalo kita mengautomisasikan yang emang bisa diautomisasikan. Karena kan itu kena cost lagi, terus kena ke respond time lagi dan seterusnya. Nah terus setelah melakukan beberapa benchmark, jadi chatbot ini cukup happening lah, karena waktu itu kita melihat kalo di Indonesia belum ada, waktu itu kita liatnya keluar, sempet ke Singtel yang di Singapura juga ada gitu kan. (Wandi Yanuar Fernando, 22 Mei 2019)

Namun, lebih spesifiknya lagi, Wandi bercerita bahwa keberadaan asisten virtual Telkomsel ini juga sebagai jawaban dari adanya sekelumit isu yang sering kali terjadi di lapangan-bentuk pelayanan pelanggan yang konvensional. Isu-isu tersebut diantaranya adalah traffic atau antrian panjang pelanggan - baik itu di media sosial, Grapari maupun call center, waktu respon yang lama, keterbatasan jumlah agen yang menangani, dan pengeluaran dana operasional. Selain itu juga ditambah dengan jenis informasi yang ingin diketahui pelanggan tergolong cukup umum seperti info PUK, info pin T-Care, info tagihan, paket, pulsa dll. Dari pain points tersebut kemudian tim Customer Care Management Telkomsel memiliki ide untuk mengautomisasi keseluruhan isu tersebut menjadi satu layanan praktis yang dapat digunakan oleh pelanggan, tanpa harus bersusah payah menghubungi ataupun mendatangi agen Telkomsel di Grapari maupun kanal layanan pelanggan lainnya.

Harapannya emang pada awal pembuatannya emang kita ke service-oriented. Jadi kaya info PUK, info Grapari, info pin t-care, ebill dan seterusnya itu yang berulang kali muncul di touch-point kita karena kan di subdir ini juga menghandle Grapari dan call in, jadi kita lihat dari KIP yang sering muncul ini apa sih, oh ternyata emang KIP-KIP yang memang bisa diautomisasi. Jadi ini peluang, kita bisa menghemat cost lebih kecil lagi gitu, lalu traffic, kemudian kita bisa memastikan respond time itu lebih cepat dan lebih real time. Make sense kalo kita buat ini, kita bisa satu menghemat menurunkan expense operasional, kemudian juga memastikan respond time yang cepat. Kapan aja 24 jam 7 hari. Itu sih alasannya kenapa kita buat asisten virtual. (Wandi Yanuar Fernando, 22 Mei 2019).

Lebih lanjut, kehadiran asisten virtual ini memang ditujukan untuk mengurangi jarak fisik dan temporal dari merek dengan memberikan pelanggan akses yang mudah ke informasi produk (Chung et al., 2018). Dalam industri layanan, sistem layanan pelanggan yang sudah diberdayakan oleh teknologi informasi ini juga mewakili kumpulan sistem informasi yang memungkinkan kinerja layanan pelanggan dengan tujuan meningkatkan kinerja pelayanan pelanggan. Sistem ini dilatih untuk memprediksi dan mengidentifikasi 
Rangga Putera Perdana, Irwansyah: Implementasi Asisten Virtual Dalam Komunikasi Pelayanan Pelanggan (Studi Kasus Pada Layanan Pelanggan Telkomsel)

kebutuhan pelanggan serta bereaksi pada permintaan pelanggan dengan cepat dan efektif, sehingga perusahaan dapat mempersonalisasi layanan yang diberikan (Piccoli et al., 2017).

Guna mempermudah interaksi antara pelanggan dengan asisten virtual Telkomsel, Wandi menjelaskan bahwa Telkomsel menggunakan teknologi chatbot dan kecerdasan buatan/AI dalam membangun Veronika. Chatbot digunakan sebagai media interaksinya sedangkan AI digunakan untuk "otak" dalam memproses masukan dari pelanggan dan meresponnya. Teknologi chatbot ini menawarkan lapisan dukungan dalam format terbaru untuk layanan yang memiliki dimensi kualitas dengan memastikan bahwa layanan yang dipersonalisasi ini dapat diakses dalam pemenuhan kebutuhan pelanggan kapan saja dan dimana saja (Chung et al., 2018). Chatbot ini menggunakan media teks untuk mewadahi interaksi yang dibangun. Pada lapisan berikutnya, baru terdapat AI sebagai kendali yang mengoperasikan keseluruhan proses dalam wadah chatbot tersebut.

Awalnya kan chatbot, mulai dari chat., dan artificial intelligent. Kalo kita comes up sama nama chatbot, orang akan berpikir ini robot ini cuman buat main-main, ini gak bisa membantu. Nah kemudian kita mulai sebenernya ini juga kan seperti asisten virtual kita. Harapan kedepannya dia akan bisa mengingatkan kita tentang pulsa anda mau habis, saatnya bayar tagihan, ada paket surprise deal, dan lainlain. Kalo kita menjadikan touch-point kita ini jadi asisten, kan jadi lebih personalize gitu loh. Jadi kita comes up dengan nama asisten virtual, walaupun ya emang teknologinya namanya chatbot juga. Jadi chatbot itu terdiri dari beberapa things atau beberapa itemlah misalnya kita menggunakan juga kata(dot)AI. Kata(dot)AI itu sebagai library directorynya. Jadi itu mereka itu yang ee mereka itu sebuah perusahaan yang emang menggabungkan satu Subjek, Predikat, Objek. Jadi kalo dia jawab $S+P+O$ ini artinya apa? Gitu. (Wandi Yanuar Fernando, 22 Mei 2019).

Spesifiknya chatbots bekerja dalam dua cara yang berbeda. Pertama, obrolan dalam format teks dapat memberikan respon sederhana berdasarkan perintah tertentu. Penggunaan chatbots menjadi keputusan yang efektif dengan didukung kehadiran AI yang terbatas. Dalam cara yang pertama ini, chatbots hanya sebatas pada bahasa pemograman mereka dan cenderung melakukan usaha lebih jika dihadapkan pada pertanyaan atau situasi yang lebih kompleks. Ini didukung dengan pernyataan dari Wandi, yang menyebutkan bahwa implementasi AI pada teknologi chatbots asisten virtual Telkomsel tidak sepenuhnya dikendalikan oleh robot. Tetap ada bantuan agen/orang jika chatbots dirasa tidak dapat menyelesaikan masalah yang disampaikan oleh pelanggan.

Jadi menurut saya AI itu ada beberapa versi sih, ada yang memang otaknya belajar sendiri, tapi itu udah sangat advance. Jadi kalo yang dikami, orangnya itu hanya untuk input memasukkan inputan-inputan yang dateng dari pelanggan, misalnya ada beberapa inputan pelanggan yang dunno. Jadi ada yang dimengerti, ada yang dunno tapi masuk FAQ, ada yang bener-bener dunno. Yang bener-bener dunno Inilah yang kita coba cari, kenapa sih masih dunno, misal kayak saya ingin beli pulsa untuk beli paket. Sebenernya kan kita udah punya flow untuk beli paket dan flow untuk beli pulsa. Cuman si AInya akan bingung nih, ini orang mau beli pulsa atau beli paket? Nah hal-hal seperti itu yang masih membutuhkan manusia. Sekitar 
15-20\% masih ada campur tangan manusianya ya untuk pengoperasiannya untuk melatihnya memang butuh manusia. Selain itu ketika misalnya dua kali tidak berhasil dijawab chatbot akan lempar nih ke agent untuk dibantu. Setelah dilempar ke agent kita akan nunggu, kita gak akan interrupt, chatbot gak akan interrupt sampai nanti agentnya bilang oke masalah sudah selesai silahkan kamu ambil alih lagi. (Wandi Yanuar Fernando, 22 Mei 2019).

Lalu, pada cara yang kedua, AI yang berkolaborasi dengan chatbots secara artifisial dapat menjawab pertanyaan kontekstual dengan belajar dari interaksi sebelumnya atau melalui percakapan yang semu. Chatbot ini dibangun di atas kemampuasn bahasa pemograman alami-Natural Languange Program-atau pemahaman bahasa pemograman-Natural Language Understanding — dengan meniru penggunaan jaringan saraf pada otak manusia (Simon, 2019).

Kecerdasan buatan yang diimplementasikan pada asisten virtual Telkomsel ini memiliki tujuan untuk menganalisis, memproses dan merespon bentuk masukan yang dilakukan oleh pengguna. Di sisi ini, AI dilatih untuk "belajar" tentang perilaku yang ditunjukkan pelanggan melalui tatanan bahasa yang mereka gunakan. Belajar ini dapat diartikan sebagai data fase elistasi dan pengumpulan dimana organisasi mengumpulkan preferensi pelanggan melalui interaksi antara penyedia layanan dan pelanggan. Ini terjadi secara langsung dengan meminta individu untuk secara eksplisit mengekspresikan suka atau tidak suka mereka, sehingga secara tidak langsung dapat menyimpulkan preferensi dari perilaku actual dan interaksi sebelumnya (Piccoli et al., 2017). Selanjutnya, dalam personalisasi layanan, pencocokan informasi terdiri dari beberapa langkah, diantaranya iaah melakukan modifikasi komponen tertentu dari penawaran layanan - termasuk pada pengiriman layanan, produk layanan dan lingkungan layanan-yang didasarkan pada profil pelanggan. Hasil dari inilah yang kemudian dipersonalisasi, dimonitor oleh AI dan menjadi umpan balik untuk personalisasi yang lebih baik pada layanan yang akan datang.

Jadi kita latih ke sistem mereka. Kita menggunakan kata(dot)AI, terus kita juga menggunakan ee ada beberapa. setelah dari kata(dot)AI kita combine dengan beberapa tools yang dipunyai kita, kita pake UXP, digicore, kemudian kita pake OSB. Jadi dari kata(dot)AI itu tersebut.. sama sama withAI. Kalo kata(dot)AI Bahasa Indonesia, withAI itu Bahasa inggris. Terus beberapa teknologi itu kita combine, harapannya sih nanti ketika nanti masuk voice juga ya dari kata(dot)AI ini yang akan support dari teks ke voicenya. Saat ini masih mendefinisikan apa itu keinginan pelanggan, kemudian emosinya bagaimana, terus nanti dia akan memikirkan kalo misalnya ada dua kemungkinan harusnya dia akan memberikan saran, maksudmu itu yang A atau yang B? untuk tidak sampe salah gitu. (Wandi Yanuar Fernando, 22 Mei 2019).

Saat ini teknologi AI yang digunakan asisten virtual Telkomsel masih terbatas pada versi satu. Versi satu ini merupakan dasar pemikiran dari proses pemahaman interaksi antara pelanggan dengan AI. Dalam versi ini AI hanya baru bisa memahami bentuk pertanyaan atau pernyataan standar dengan tatanan bahasa sesuai dengan EYD. Dalam versi satu ini pulalah dikenal dengan istilah NLP/NLU yang menjadi acuan pada bahasa pemograman yang digunakan AI. 
Rangga Putera Perdana, Irwansyah: Implementasi Asisten Virtual Dalam Komunikasi Pelayanan Pelanggan (Studi Kasus Pada Layanan Pelanggan Telkomsel)

Semakin banyak padanan kata yang dimasukkan dalam NLP/NLU makan akan semakin mudah AI dalam memproses pertanyaan atau pernyataan yang diutarakan oleh pelanggan.

Si AInya itu akan mikir pulsa ini banyak definisinya, dari situ dia akan masuk ke rule kedua dan ini memang sering misleading. Dia akan hitung, pulsa ini kan satu kata, dari semua tren yang ada di semesta NLU, natural language understanding, mana sih yang paling banyak satu kata satu kata. Ada beberapa intention, oh ini kebanyakan satu kata semua nih, tapi dia akan secara otomatis, karna satu kata maka akan sama dengan satu kata yang ini. (Wandi Yanuar Fernando, 22 Mei 2019).

Pada bentuk pengembangan selanjutnya, yaitu versi tiga, AI akan dirancang dan dilatih untuk memahami emosi pelanggan. Ini dilakukan untuk semakin membuat aspek personalisasi dari asisten virtual Telkomsel terasa oleh pelanggan. AI akan dapat mendeteksi emosi pelanggan melalui bagaimana mereka menuliskan teks/chat pada kanal yang dipilih. Salah satu contoh penerapannya yaitu teknologi AI versi tiga akan mendefinisikan penggunaan huruf kapital sebagai emosi marah pelanggan. Dari situ AI akan menyesuaikan respon dengan harapan pelanggan tidak semakin merasa emosional-marah. Selain itu, versi tiga ini juga mendorong AI untuk dapat memastikan pelanggan dari dua pilihan yang muncul dari masukan pelanggan. Ini dilakukan untuk menimalisir kesalahan dan meningkatkan hubungan personal antara AI dengan pelanggan.

Sekarang masih versi satu yang digunain, lagi on going ke versi tiga itu bisa ke sentiment analysis. Jadi mereka akan ngerti kalo lagi marah dengan lihat oh ini capital lock nih, berarti ni marah jangan lagi..,ekspektasinya kalo mereka marah jangan lagi chatbot yang handle, langsung misalnya mungkin ke human. Kalo dia lagi senang, dia lagi ulangtahun, kita kasih sesuatu. Sejauh ini sih masih tadi ya, masih mendefinisikan apa itu keinginan pelanggan, kemudian emosinya bagaimana, terus nanti dia akan memikirkan kalo misalnya ada dua kemungkinan harusnya dia akan memberikan saran, maksudmu itu yang A atau yang B? untuk tidak sampe salah gitu. (Wandi Yanuar Fernando, 22 Mei 2019).

Saat ini, media yang digunakan asisten virtual Telkomsel dalam menjangkau pelanggannya ialah layanan jejaring sosial Facebook Messenger, Line dan Telegram. Selain itu tim pengembangan juga menambahkan asisten virtual Telkomsel pada kanal resmi Telkomsel seperti situs telkomsel.com dan aplikasi myTelkomsel. Alasan pemilihan tiga layanan jejaring sosial yang disebutkan sebelumnya itu didasarkan pada kemampuan masing-masing platform dalam menampung teknologi chatbots dan AI. Alasan lainnya itu lebih mengacu pada kuantitas massa/pengikut yang dimiliki oleh jejaring sosial tersebut. Satu hal yang harus digarisbawahi untuk penggunaan chatbot pada jejaring sosial Line, Wandi bercerita bahwa sampai saat ini hanya Line saja yang dapat mengakomodir fungsi Official Account dan digabungkan dengan fungsi chatbot.

Kalo channel sih kita udah ada di Facebook Messenger, Line Messenger, Telegram. Terus kita udah embed di telkomsel.com, kemudian di myTelkomsel juga sudah ada, apps. Yang pertama implement chatbot ini kan ada tiga ni, Line, Facebook sama 
Telegram. Kenapa Line sama Facebook? Karena kita udah punya massa disitu, kita udah kelola Line, kita udah kelola Facebook, sudah ada followers nya dan mereka sudah terbuka untuk implement chatbot di platform mereka. Kenapa telegram? Mungkin pada saat itu yang paling cepat dan paling mudah integrasinya itu Telegram, karena itu open source. Jadi kita gak ada campur tangan sama Telegram $H Q$, kita memang langsung cari API API di telegram terus kita implementasi. Untuk Line, jadi dibelakang itu ada dua otak lah, jadi kayak hybrid gitu lah. Kita assist lagi ke Line, apakah memungkinkan hybrid? Ada yang emang OA, ada yang emang chatbot? Mereka memungkinkan, terus yaudah kita implementasi chatbot ini di OAnya yang eksisting. (Wandi Yanuar Fernando, 22 Mei 2019).

Lalu pada akhirnya, bentuk pengembangan yang dilakukan tim pengembangan asisten virtual Telkomsel ini akan berfokus pada empat hal, yaitu penambahan kanal jejaring sosial yaitu WhatsApp, lalu peningkatan padanan kata di NLU/NLP untuk membantu AI dalam merespon pelanggan, melakukan migrasi teknologi AI dari versi satu ke versi tiga - terutama pada penambahan fungsi personalisasi emosi pelanggan dan yang terakhir yaitu melakukan kolaborasi dengan Google melalui asisten virtual Google Assistant kepemilikannya. Khusus untuk pengembangan yang terakhir disebutkan itu, Wandi menjelaskan bahwa mereka telah melakukan diskusi dengan Google dengan harapan Google Assistant dapat berintegrasi dengan Veronika, jika terdapat kondisi pelanggan melakukan pendekatan awal tentang keluhan produk Telkomsel melalui Google Assistant. Sehingga nantinya, Google Assistant dapat meneruskan keluhan pelanggan tersebut ke Veronika. Satu yang harus digaribawahi dalam implementasi ini ialah kemampuan AI dalam mendeteksi suara dan melakukan integrasi antara dua sistem yang berbeda. Wandi menyebutkan bahwa kolaborasi ini merupakan ekspektasi jangka panjang yang mereka harapkan.

Kalo yang paling deket itu, kita akan nambah channel ke whatsapp. Jadi kita pake API business for whatsapp, jadi gak ada fisiknya. Sekarang udah jalan tapi masih beta, masih internal yang gunain. Karena memang yang pake chatbot di whatsapp ini masih sedikit, terutama di Indonesia. kemudian, yang tadi aku sempet mentiom tentang sentiment analysis tadi. Terus selanjutnya itu tentang yang pake Google Assistant. Kita sudah beberapa kali ketemu sama Google. Jadikan ketika mereka ngomong, ngobrol sama telkomsel dong, nanti secara sistem ini Google Assistant ini akan memforwardkan ke Veronika, asisten virtual kita by voice command. Tapi itu emang masih tahap diskusi awal. Paling yang beberapa enhancement itu seperti FAQ kita, kita akan coba perbaiki lagi. (Wandi Yanuar Fernando, 22 Mei 2019).

Komunikasi yang mulanya dikenal hanya sebatas perpindahan pesan dari pengirim ke penerima, kini sudah memiliki cakupan yang lebih luas. Teknologi membantu komunikasi dalam memudahkan proses penyampaian pesan dengan respon yang dapat diterima saat itu juga. Komunikasi dalam bidang pelayanan pelanggan juga mengalami perkembangan yang cukup signifikan. Jika dahulu pelanggan harus mengunjungi kantor cabang terdekat untuk dapat dilayani secara tatap muka dengan bagian layanan pelanggan, saat ini berkat adanya bantuan teknologi komunikasi, pelanggan dapat dengan mudah mengakses layanan pelanggan melalui telepon genggamnya saja. Kemudahan ini tentunya 
harus didukung oleh banyak komponen seperti perangkat keras, perangkat lunak, serta jaringan Internet. Pelanggan diberikan kebebasan dan pilihan dalam menyampaikan keluhannya dengan beragam kanal/media pelayanan.

Dalam ranah komunikasi terutama yang berkaitan langsung dengan layanan pelanggan, kehadiran teknologi asisten virtual ini memberikan ruang lebih bagi setiap individu dalam mendapatkan hak jasa-nya sebagai seorang pelanggan. Pada penelitian ini, kehadiran asisten virtual dalam proses komunikasi pelayanan pelanggan dapat didefinisikan sebagai suatu saluran/media dalam menyampaikan informasi kepada pelanggan. Walaupun asisten virtual ini diciptakan untuk mengganti agen pelayanan pelanggan, namun hal tersebut tidak merubah posisinya sebagai pengirim atau sumber informasi. Seperti yang sudah dipaparkan diatas bahwa informasi dan respon yang disampaikan oleh asisten virtual ini masih dilakukan manual oleh individuindividu dalam tim pengembang dari perusahaan. Sehingga dapat dikatakan bahwa peran asisten virtual disini hanya sebagai perantara ataupun media penyampai pesan. Pelanggan memang seolah-olah dihadapkan pada agen pelayanan pelanggan secara maya, namun jika melihat prosesnya, respon yang keluar dari asisten virtual itu bukanlah informasi yang mereka hasilkan sendiri.

\section{Simpulan}

Asisten virtual Telkomsel menggunakan teknologi chatbot dan kecerdasan buatan - atau AI dalam melakukan tugasnya sebagai representatif maya dari agen Telkomsel. Chatbot ini menawarkan dukungan dalam format terbaru untuk layanan yang memiliki dimensi kualitas dengan memastikan bahwa layanan yang dipersonalisasi ini dapat diakses dalam pemenuhan kebutuhan pelanggan kapan saja dan dimana saja. Saat ini chatbot yang digunakan Veronika masih sebatas teks. Untuk memahami teks yang ditulis oleh pelanggan saat mengakses Veronika, tim pengembangan asisten virtual Telkomsel ini lalu menggunakan kecerdasan buatan dalam mendefinisikan maksud dan tujuan dari pelanggan.

Dalam implementasinya, ternyata AI masih dibantu sumber daya manusia dalam mempelajari dan memahami maksud dari pertanyaan atau pernyataan pelanggan. Tim akan terus melatih AI menggunakan NLP-Natural Language Program atau NLU-Natural Language Understanding agar semakin memperkaya pemahaman AI dalam padanan kata yang ditujukan ke mereka. Implementasi asisten virtual Telkomsel ini menggunakan jejaring sosial yang memungkinkan untuk open source dengan bawaan teknologi chatbot dan AI. Jejaring sosial yang sudah digunakan saat ini yaitu Facebook Messenger, Line dan Telegram. Selain itu, Veronika juga sudah terimplementasi pada situs Telkomsel, dan aplikasi myTelkomsel. Adapun pemilihan ketiga jenis jejaring sosial tersebut didasarkan pada kemampuan mereka dalam menampung teknologi chatbot dan AI.

Penelitian mengenai asisten virtual dalam dunia komunikasi-terutama pada bidang pelayanan pelanggan-masih sangat minim. Penelitian ini dapat menjadi salah satu referensi untuk memperluas kajian komunikasi pelayanan 
pelanggan seperti mengukur efektivitas komunikasi asisten virtual, tingkat kepuasan pelanggan yang menggunakan layanan asisten virtual dan lain-lain.

\section{Ucapan Terima Kasih}

Penulis mengucapkan rasa terima kasih kepada seluruh narasumber. Rasa terima kasih diberikan atas kesediaan dan kerjasama yang diberikan.

\section{Daftar Pustaka}

Atmoko, B. D. (2017). Veronika, Asisten Virtual Telkomsel dengan Kecerdasan Buatan. Retrieved May 23, 2019, from https://gizmologi.id/berita/veronika-asisten-virtual-telkomsel/

Beaver, I., \& Freeman, C. (2017). Analysis of user behavior with multimodal virtual customer service agents. 2016 IEEE Workshop on Spoken Language Technology, SLT 2016 - Proceedings, 585-591. https://doi.org/10.1109/SLT.2016.7846322

Bernard, D., \& Arnold, A. (2019). Cognitive interaction with virtual assistants: From philosophical foundations to illustrative examples in aeronautics. Computers in Industry, 107, 33-49. https://doi.org/10.1016/j.compind.2019.01.010

Chung, M., Ko, E., Joung, H., \& Kim, S. J. (2018). Chatbot e-service and customer satisfaction regarding luxury brands. Journal of Business Research, (November 2017), 1-9. https://doi.org/10.1016/j.jbusres.2018.10.004

Guzman, A. L. (2019). Voices in and of the machine: Source orientation toward mobile virtual assistants. Computers in Human Behavior, 90(August 2018), 343-350. https://doi.org/10.1016/j.chb.2018.08.009

Kamil, M. F. (2016). Pengaruh Gadget Berdampak Kepada Kurangnya Komunikasi Tatap Muka Dalam Kehidupan Sehari- Fakultas Dakwah Dan Ilmu Komunikasi Institut Agama Islam Negeri ( Iain ) Raden Intan Lampung Pengaruh Gadget Berdampak Kepada Kurangnya Komunikasi Tatap Muka Dalam Ke.

Lasek, M. (n.d.). Karolina Kuligowska Virtual assistants support customer relations and business processes. Retrieved from http://kuligowska.com/papers/Kuligowska_Lasek_Virtual_assistants_2 011.pdf

Netti, S. Y. M. (2018). Spotify: Aplikasi Music Streaming untuk Generasi Milenial. Jurnal Komunikasi Universitas Tarumanagara, 10(1), 1-16.

Piccoli, G., Lui, T. W., \& Grün, B. (2017). The impact of IT-enabled customer service systems on service personalization, customer service perceptions, and hotel performance. Tourism Management, 59, 349-362. https://doi.org/10.1016/j.tourman.2016.08.015

Simon, J. P. (2019). Artificial intelligence: scope, players, markets and geography. Digital Policy, Regulation and Governance . https://doi.org/10.1108/DPRG-08-2018-0039 